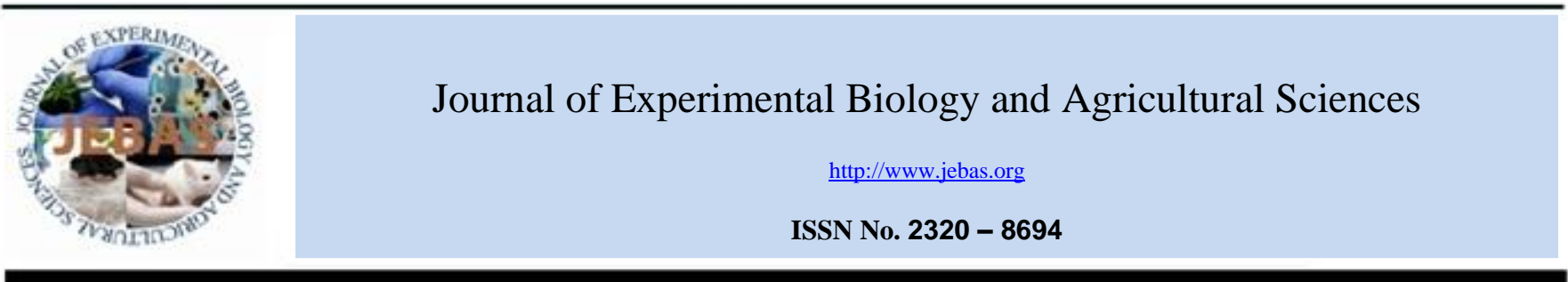

\title{
IN-VITRO ANTIMYCOTIC ACTIVITY OF SELECTED ESSENTIAL OILS AND FUNGICIDES AGAINST Aspergillus niger AND Fusarium oxysporum
}

\author{
Chandi C. Rath ${ }^{*}$, Alena Patnaik \\ Department of Botany, College of Basic Science and Humanities, Orissa University of Agriculture and Technology, Bhubaneswar, India- 751003 \\ Received - December 27, 2017; Revision - April 06, 2018; Accepted - June 15, 2018 \\ Available Online - June 20, 2018
}

DOI: http://dx.doi.org/10.18006/2018.6(3).490.497

\author{
KEYWORDS \\ Aspergillus niger \\ Fusarium oxysporum \\ Essential oils \\ Minimum inhibitory \\ concentration (MIC) \\ Minimum killing time (MKT) \\ Fungicides
}

\begin{abstract}
In the present study, eight different essential oils (Basil, Citronella, Neem, Turmeric, Eucalyptus, Pipermint, Palmarosa, Lemongrass) were tested for their antifungal activities against Aspergillus niger and Fusarium oxysporum. Result of the study revealed that all the tested essential oils showed fungicidal properties against these two test pathogens. Among the eight essential oils tested, Citronella oil showed maximum antifungal activities and this was followed by Lemongrass and Pipermint. The MIC value of the oils ranged from $0.97-500 \mu \mathrm{l} / \mathrm{ml}$. The Minimum Killing Time (MKT) of the oils varied from 0 min to $5 \mathrm{hrs}$, at room temperature. Fungicidal activity of the oils retained even after treating at $100^{\circ} \mathrm{C}$ for an hour and on autoclaving $\left(121^{\circ} \mathrm{C}\right.$ and $15 \mathrm{lb}$ pressure for $\left.20 \mathrm{~min}\right)$, which indicated thermostable and barostable nature of the active components in these oils. When the effect of commercially available synthetic fungicides were studied it was observed that both the pathogens were resistant to copper chloride 50\% WP and Carbendazim 50\% WP (upto $500 \mathrm{ppm}$ ) whereas, the essential oils killed the pathogens at a very lower concentrations and observed to be fungicidal in nature.
\end{abstract}

* Corresponding author

E-mail: chandicharanrath@yahoo.com(Chandi C. Rath)

Peer review under responsibility of Journal of Experimental Biology and Agricultural Sciences.

Production and Hosting by Horizon Publisher India [HPI] (http://www.horizonpublisherindia.in/).

All rights reserved.
All the article published by Journal of Experimental Biology and Agricultural Sciences is licensed under a Creative Commons Attribution-NonCommercial 4.0 International License Based on a work at www.jebas.org.

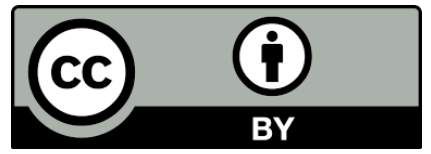




\section{Introduction}

Enormous use of chemical fertilizers, pesticides, insecticides and fungicides to increase crop yield and to fulfill the demands of growing population, have put major and severe impact on environment. The major drawback of long term use of chemical pesticides and insecticides include, their non degradability nature, they accumulate in the environment and enter into the food chain in the ecosystem resulting in biomagnifications, many are proved to be carcinogenic, being a cause of environmental pollution, affect the soil microbial population and hence decreases the soil fertility (De Cal et al., 2009; Sharma et al.,2016a; Carvaloh, 2017).

Among the various fungal phytopathogens Fusarium oxysporum and Aspergillus niger are common in causing devastation in plants (Samson et al., 2004). Common symptoms like stunted growth, damping off, discolouration of vascular system, premature leaf fall are observed in crops due to Fusarium wilt (Hashem et al., 2010). Whereas, A. niger is a common post harvest pathogen of fruits and vegetables (Sharma, 2012).

Traditionally, the chemical treatments by the application of synthetic fungicides are considered to be the most effective and cheapest method in controlling the plant diseases. But, the development of multiple fungicide resistance among the pathogens is well documented in literature and is of global concern today (Deising et al., 2008). The growing concern for human safety and the potential impact on environment largely limits their application and compels the academicians and researchers to look for alternative to the use of fungicides to control the plant diseases. Recently interest has been generated on use of Phytochemicals as they are considered to be environmentally safe as they are biodegradable and have little or no toxicity to nontarget organisms (Linde et al., 2006). Among all the chemicals and secondary metabolites produced in a plant the preferred choice by academician and the researchers is the essential oils. Plant essential oils are concentrated hydrophobic liquids extracted from different parts of medicinal and aromatic plants (Pawar \& Thaker 2007), and several essential oils are known to possess antimicrobial, antifungal and insecticidal properties (Chutia et al., 2009; Siddique et al. 2017). Furthermore, antifungal activities of several essential oils are reported by various researchers (Beg \& Ahmad 2002; Deng et al., 2013; Tejeswini et al., 2014; Rath \& Mohapatra 2015). This prompted us to use selected essential oils (Pipermint, Eucalyptus, Plamarosa , Basil , Citronella, Lemongrass, Turmeric and Neem ) to screen for their antifungal properties against these two pathogens in comparison to selected fungicides ( Curex, Zim-50 \& Relaxyl).

\section{Materials and Methods}

\subsection{Pathogens}

The test pathogens viz. A. niger (MTCC- 5448) and F. oxysporum (MTCC- 4998) used in the study were procured from P.G. Department of Microbiology, College of Basic Science and Humanities, OUAT, Bhubaneswar, India.

\subsection{Essential oils}

Eight different essential oils viz., Pipermint (Mentha piperita) from sourthern spices, Madurai, Eucalyptus (Eucalyptus deglupta) from CIMAP, Hyderabad, Plamarosa (Cymbopogon martini), Basil (Ocimum basilicum), Citronella (Cymbopogon nardus), Lemongrass (Cymbopogon citrates) from Flower and Fragrance Development Corporation, Berhampur, Odisha, Turmeric (Curcuma longa) and Neem (Azadirachta indica) procured from Oil and technological Research Institute, JNTU, Anantapur, Hyderabad were used in the study in order to assess their antifungal potentials.

\subsection{Media and Chemicals}

Potato Dextrose Agar (PDA), Potato Dextrose Broth (PDB), Tween 20 were procured from Hi-Media Ltd. Mumbai, India and all the media were prepared according to manufacturer's instruction. The media were supplemented with $0.75 \%$ of Tween 20 (T-20) to facilitate the miscibility of the oils.

\subsection{Methods}

2.4.1 Screening of essential oils against phytopathogens by disc diffusion method (DDM)

For the primary screening of the oils, Disc Diffusion Method (DDM) described by Bauer et al., (1966) was used. Sterile filter paper discs $(5 \mathrm{~mm})$ were loaded with $10 \mu \mathrm{l}$ of respective oils separately and applied to precultured (from $24 \mathrm{hr}$. old culture on PDA plates) fungal colonies on PDA plates and incubated. Plates were observed for growth inhibition of colonies after incubation at $25^{0} \mathrm{C}$ for 5 days.

\subsubsection{Determination of the Minimum Inhibitory Concentrations (MIC) of the oils}

Two fold tube dilution method proposed by Rath et al., (1999) was used with some modifications to determine the Minimum Inhibitory Concentration (MIC). In brief, Tween 20 (0.75\%) supplemented Potato Dextrose Agar (PDA) was dispensed in $1 \mathrm{ml}$ amount into the test tubes and sterilized. With the help of a sterile pipette, $1 \mathrm{ml}$ of the oil was transferred to the first tube and mixed by vortexing for a homogenous emulsion. Further, the samples 
were serially diluted as two fold dilution. From the $10^{\text {th }}$ tube $1 \mathrm{ml}$ of emulsion was discarded and the tubes were kept in slanting position to obtain oil-PDA slants. After solidification, fungal culture discs $(5 \mathrm{~mm})$ were inoculated into the slants and incubated at $25^{\circ} \mathrm{C}$ for $48 \mathrm{hrs}$. PDA slants without oil served as control. After the incubation period the tubes were observed for the fungal growth. No growth of the test organism at a particular concentration was determined as MIC for that oil.

\subsubsection{Determination of Minimum Killing Time (MKT)}

Potato Dextrose Agar plates were prepared as per manufacturer's instruction. Three day old mat of A. niger and F. oxysporum culture was taken and fungal discs $(5 \mathrm{~mm})$ were punched using a sterile cork borer. Under aseptic conditions, these discs were treated in the oils for 1, 2, 5, 15 and 30minutes for $1 \mathrm{hr}, 2 \mathrm{hrs}, 3 \mathrm{hrs}$, $4 \mathrm{hrs}$ and $5 \mathrm{hrs}$ in a sterile watch glass under aseptic condition. The treated fungal discs were transferred onto PDA plates, and incubated at $25^{\circ} \mathrm{C}$ for $48 \mathrm{hrs}$. The plates were observed for growth. No growth on sub-culturing at a particular time is considered as minimum killing time for that oil. The same procedure was followed to determine the MKT value for different oils against the test pathogens.

\subsubsection{Effect of high temperature and pressure on antifungal activity of the essential oils}

This experiment was designed to study the effect of temperature (by boiling the oils at high temperature) and pressure (autoclaving the oils) on antifungal activity of the test oils by disc diffusion method. PDA plates were prepared and inoculated with fungal culture discs. Sterile filter paper discs of $5 \mathrm{~mm}$ diameter were mounted on the surface of the plates at equal distance. All the oils were heated at $100^{\circ} \mathrm{C}$ for one hour (in the water bath) and autoclaved at $121^{\circ} \mathrm{C}$ and $15 \mathrm{lb}$ pressure for 20mins. Using a sterile pipette MIC value of above treated oils were loaded over the sterile filter paper discs and incubated at $25^{\circ} \mathrm{C}$ for $48 \mathrm{hrs}$. Plates were observed for growth inhibition of the fungal mat around the discs which indicates positive antifungal activity of the treated oils, in comparison to control.

\subsubsection{Effect of essential oils on dry matter percentage (DM\%) reduction of the test pathogens}

This experiment was designed to determine, the effect of essential oils (at MIC level) on percentage DM reduction of the test pathogens. $50 \mathrm{ml}$ of PDB was prepared in $100 \mathrm{ml}$ conical flasks, supplemented with $0.75 \%(\mathrm{~V} / \mathrm{V})$ of Tween 20 . The MIC level of oils and fungicides were added to the conical flasks, separately. The above flasks were inoculated with $5 \mathrm{~mm}$ discs of fungal mats and incubated at $25^{\circ} \mathrm{C}$ for $120 \mathrm{hr}$. After incubation period, the fungal culture was filtered through a Whatman No-1 filter paper that was squeezed on a dry blotting paper to remove excess liquid present, weighed and considered as fresh weight. The fungal mycelium along with the filter paper was dried in a hot air oven at $70^{\circ} \mathrm{C}$ for $4 \mathrm{hrs}$, weighed and considered as dry weight. The dry matter $\%$ was determined by using the formula

$\mathrm{DM} \%=\frac{\text { Fresh weight of the culture }- \text { dry weight of the culture }}{\text { fresh weight }} \times 100$

2.4.6 Effect of different fungicides against test pathogens, and comparison of activity with essential oils

This experiment was conducted to study the effect of selected commercially used fungicides against the test pathogens, by following the method of Amin \& Sidovich (2010), with slight modifications. Three different fungicides; ZIM 50 (Carbendazim 50\% WP, systemic fungicide), CUREX (Copper Oxychloride $50 \%$ WP, contact fungicide), RELAXYL ( Metalaxyl 80\% and Mancozeb 64\% WP, contact-systemic fungicide); were taken and a stock solution was prepared. PDA slants with different concentrations of fungicide $(1,3,5,10,20,30,100,200,300$, $400,500 \mathrm{ppm}$ ) were made. PDA slants without fungicides were considered as control. After the solidification, the slants were inoculated with $4 \mathrm{~mm}$ diameter discs of test pathogen and incubated for $48 \mathrm{hrs}$ at $25^{\circ} \mathrm{C}$. After the incubation period the tubes were observed for the fungal growth. No growth of the pathogens at a particular concentration was determined as MIC for that particular fungicide.

\section{Results}

3.1 Screening of essential oils against phyt-opathogens by disc diffusion method (DDM)

All tested essential oils showed antifungal activities against both the tested pathogens when $10 \mu 1$ of oil was applied on the discs. The activity of the oils differed from each other in terms of zones of inhibition (Table 1). The zone of inhibition ranged from 6$45 \mathrm{~mm}$. Eucalyptus oil showed similar effect against A. niger and F. oxysporum in terms of zone of inhibition $(6 \mathrm{~mm} \mathrm{\&} 7 \mathrm{~mm})$ respectively. Citronella oil showed maximum zone of inhibition against $A$. niger (45mm), whereas, Pipermint, Lemongrass, Basil and Citronella showed similar activity against $F$. oxysporum with a maximum zone of inhibition (34mm).

\subsection{Determination of the Minimum Inhibitory Concentrations (MIC) of the oils}

The MIC value of the oils ranged between $0.97 \mu 1 / \mathrm{ml}-500 \mu 1 / \mathrm{ml}$ (Table 2). Lowest value of MIC $1.9 \mu \mathrm{l} / \mathrm{ml}$ was observed in case of lemongrass and palmarosa oil against F.oxysporum whereas, the highest value of MIC, $500 \mu \mathrm{l} / \mathrm{ml}$ of neem oil was reported against both the test pathogens. Pipermint oil showed the MIC value of 
Table 1 Antifungal activity of the essential oils against test pathogens

\begin{tabular}{|cccc|}
\hline \multirow{2}{*}{ S. } & Essential oils & \multicolumn{2}{c|}{$\begin{array}{c}\text { Growth Inhibition (Inhibition zone in mm) } \\
\text { Pathogens }\end{array}$} \\
No. & & Aspergillus niger & Fusarium oxysporum \\
\hline 1 & Pipermint oil & $13 \pm 1.34^{\mathrm{d}}$ & $34 \pm 0.12^{\mathrm{b}}$ \\
\hline 2 & Palmarosa oil & $12 \pm 1.35^{\mathrm{d}}$ & $18 \pm 0.56^{\mathrm{d}}$ \\
\hline 3 & Lemongrass oil & $42 \pm 0.26^{\mathrm{a}}$ & $34 \pm 0.12^{\mathrm{b}}$ \\
\hline 4 & Neem Oil & $13 \pm 1.35^{\mathrm{d}}$ & $09 \pm 0.91^{\mathrm{e}}$ \\
\hline 5 & Eucalyptus oil & $06 \pm 0.68^{\mathrm{e}}$ & $07 \pm 0.98^{\mathrm{e}}$ \\
\hline 6 & Basil Oil & $44 \pm 0.13^{\mathrm{a}}$ & $34 \pm 0.12^{\mathrm{b}}$ \\
\hline 7 & Citronella oil & $45 \pm 0.15^{\mathrm{a}}$ & $34 \pm 0.12^{\mathrm{b}}$ \\
\hline 8 & Turmeric Oil & $13 \pm 1.35^{\mathrm{d}}$ & $06 \pm 0.75^{\mathrm{e}}$ \\
\hline$*$ Zone of inhibition was measured by subtracting the diameter of the fungal
\end{tabular}

*Zone of inhibition was measured by subtracting the diameter of the fungal colony in control plate to that of diameter of fungal colony on treated plate, \pm Standard Deviation

Table 2 Minimum Inhibitory concentration of used essential oils against two selected pathogens

\begin{tabular}{|cccc|}
\hline S. No & Essential oils & $\begin{array}{c}\text { Minimum inhibitory concentration (MIC) in } \mu 1 / \mathrm{ml} \\
\text { Fusarium oxysporum }\end{array}$ & $\begin{array}{c}\text { Aspergillus niger } \\
\end{array}$ \\
\hline 1 & Pipermint oil & 3.9 & 3.9 \\
\hline 2 & Palmarosa oil & 1.9 & 3.9 \\
\hline 3 & Lemongrass oil & 1.9 & 0.97 \\
\hline 4 & Neem oil & 500 & 500 \\
\hline 5 & Eucalyptus oil & 31.25 & 6.25 \\
\hline 6 & Basil oil & 15.62 & 7.81 \\
\hline 7 & Citronella oil & 7.81 & 7.81 \\
\hline 8 & Turmeric oil & 500 & 500 \\
\hline
\end{tabular}

Table 3 Determination of Minimum Killing Time of essential oils*

\begin{tabular}{|c|c|c|c|}
\hline S. & Essential oils & \multicolumn{2}{|c|}{ Minimum killing time (MKT) in min. at room temp } \\
\hline No. & & Fusarium oxysporum & Aspergillus niger \\
\hline 1 & Pipermint oil & 120 & 120 \\
\hline 2 & Palmarosa oil & 10 & 0 \\
\hline 3 & Lemongrass oil & 10 & 0 \\
\hline 4 & Neem oil & 300 & 300 \\
\hline 5 & Eucalyptus oil & 60 & 300 \\
\hline 6 & Basil oil & 2 & 10 \\
\hline 7 & Citronella oil & 30 & 300 \\
\hline 8 & Turmeric oil & 300 & 300 \\
\hline
\end{tabular}

*Fungal discs were treated with the oils for different time intervals and subcultured into PDA plates in order to check viability or killing time.
$3.9 \mu \mathrm{l} / \mathrm{ml}$ against both the pathogens. Oil of lemongrass showed the lowest MIC of $0.97 \mu 1 / \mathrm{ml}$ against $A$. niger and $1.9 \mu \mathrm{l} / \mathrm{ml}$ against $F$. oxysporum.

\subsection{Determination of Minimum Killing Time (MKT)}

The MKT for different oils ranged from $0 \mathrm{~min}$ to $5 \mathrm{hrs}$ for both the test pathogen (Table 3). It was observed that oils of palmarosa, lemongrass showed minimum killing time to be 0 min against $A$. niger and 10 mins against $F$. oxysporum. Lemongrass, Palmarosa, Basil oils killed both the test pathogens within 15 mins. The minimum killing time for basil oil was found to be 2 mins for $F$. oxysporum and 10 mins for A. niger. The oil of Citronella showed antifungal activity against $F$. oxysporum with MKT of 30 $\min$. The MKT of pipermint oil was observed to be 120 mins for both the pathogens. Oils of turmeric and neem were not that effective as compared to other oils. Both the oils killed the test pathogens within 5hrs.

\subsection{Effect of temperature and pressure on antifungal activity of the essential oils}

Antifungal activity of all tested oils reduced by boiling and autoclaving than the normal untreated oils against $A$. niger (Table 4). But in case of citronella essential oil value of the zone of inhibition remained same as that of untreated against $F$. oxysporum. Whereas, on autoclaving the zone size slightly increased. Zone size greatly decreased in case of turmeric and neem oil when treated with high temperature and pressure against $F$. oxysporum. The oils of palmarosa showed increase in the zone of inhibition against $F$. oxysporum but this improvement was not remarkable. All the oils showed a very good activity against Aspergillus niger when treated with high pressure and temperature.

3.5 Dry matter percentage of the test pathogens with the action of essential oil

The oils of citronella and basil were proved to be highly effective against both the test pathogens. It was observed that when both the test organisms were grown in the presence of the oils (at the MIC level), in all the cases, the growth was restricted in comparison to control. In general, pipermint oil and Basil oil showed a better antifungal activity against $A$. niger in terms of decrease in Dry Matter percentage with respect to control. Surprisingly, turmeric oil, which showed lesser activities in previous experiments it showed a higher reduction in DM\% in case of A. niger whereas, Pippermint, Eucalyptus, Basil, and Citronella oils showed better activities against $F$. oxysporum in reduction 
Table 4 Effect of temperature and pressure on antifungal activity of essential oils

\begin{tabular}{cccccccc|}
\hline S. & Essential oils & \multicolumn{3}{c}{ Fusarium oxysporum } & \multicolumn{3}{c|}{ Aspergillus niger } \\
No. & & Untreated & $100^{\circ} \mathrm{C}$ & Autoclaved & Untreated & $100^{\circ} \mathrm{C}$ & Autoclaved \\
\hline 1 & Pipermint oil & $5 \pm 0.12$ & $11 \pm 0.39$ & $13 \pm 0.15$ & $14 \pm 0.17$ & $7 \pm 085$ & $7 \pm 0.15$ \\
\hline 2 & Palmarosa oil & $12 \pm 0.36$ & $13 \pm 0.36$ & $15 \pm 0.25$ & $21 \pm 0.15$ & $7 \pm 0.21$ & $7 \pm 0.13$ \\
\hline 3 & Lemongrass oil & $5 \pm 0.11$ & $12 \pm 0.23$ & $10 \pm 0.13$ & $13 \pm 0.16$ & $5 \pm 0.11$ & $5 \pm 0.12$ \\
\hline 4 & Neem oil & $21 \pm 0.36$ & $19 \pm 0.98$ & $15 \pm 0.36$ & $31 \pm 0.78$ & $5 \pm 0.10$ & $5 \pm 0.11$ \\
\hline 5 & Eucalyptus oil & $17 \pm 0.39$ & $14 \pm 0.45$ & $15 \pm 1.96$ & $26 \pm 1.26$ & $10 \pm 0.36$ & $10 \pm 0.22$ \\
\hline 6 & Basil oil & $5 \pm 0.11$ & $10 \pm 0.36$ & $12 \pm 1.10$ & $11 \pm 0.69$ & $13 \pm 0.85$ & $13 \pm 0.16$ \\
\hline 7 & Citronella oil & $5 \pm 0.12$ & $5 \pm 0.13$ & $10 \pm 0.15$ & $12 \pm 0.12$ & $9 \pm 0.89$ & $9 \pm 0.25$ \\
\hline 8 & Turmeric oil & $18 \pm 0.28$ & $5 \pm 0.11$ & $15 \pm 0.89$ & $26 \pm 1.30$ & $5 \pm 0.12$ & $5 \pm 0.12$ \\
\hline
\end{tabular}

oils were heated at $100^{\circ} \mathrm{C}$ for $1 \mathrm{hr}$ and autoclaved oil tested for antifungal activities by DDM at MIC level. Untreated i.e. oils were tested without heating or autoclaving, A- autoclaved oils, growth was observed after $48 \mathrm{hrs} ; \pm$ Standard Deviation

Table 5 Antifungal activity of the oils ${ }^{*}$ against $A$. niger and $F$. oxysporum, in terms of dry matter percentage (DM \%) reduction

\begin{tabular}{|llll|}
\hline S1. no. & Essential oils & $\begin{array}{l}\text { Aspergillus niger } \\
\text { DM\% (in mg) }\end{array}$ & $\begin{array}{l}\text { Fusarium oxysporum } \\
\text { DM\% (in mg) }\end{array}$ \\
\hline 1 & Pipermint oil & 53.00 & 53.08 \\
\hline 2 & Palmarosa oil & 63.86 & 71.10 \\
\hline 3 & Lemongrass oil & 62.18 & 64.87 \\
\hline 4 & Neem oil & 61.12 & 61.79 \\
\hline 5 & Eucalyptus oil & 64.82 & 53.84 \\
\hline 6 & Basil oil & 52.95 & 46.37 \\
\hline 7 & Citronella oil & 51.69 & 50.50 \\
\hline 8 & Turmeric oil & 50.30 & 61.22 \\
\hline 9 & Control & 74.83 & 70.70 \\
\hline
\end{tabular}

*essential oils were supplemented into the medium at MIC level

Table 6 Minimum Inhibitory Concentration of synthetic fungicides against the test pathogens

\begin{tabular}{|c|c|c|c|c|c|c|c|c|c|c|c|c|}
\hline \multirow{2}{*}{ Test organisms } & \multirow{2}{*}{ Fungicides } & \multicolumn{11}{|c|}{ Concentration (ppm) } \\
\hline & & 5 & 10 & 15 & 20 & 30 & 50 & 100 & 200 & 300 & 400 & 500 \\
\hline \multirow{3}{*}{ A. niger } & CUREX & ++ & ++ & ++ & ++ & ++ & ++ & ++ & ++ & + & + & + \\
\hline & ZIM 50 & ++ & ++ & ++ & ++ & ++ & + & + & + & - & - & - \\
\hline & RELAXYL & ++ & ++ & + & + & - & - & - & - & - & - & - \\
\hline \multirow{3}{*}{ F. oxysporum } & CUREX & ++ & ++ & ++ & ++ & ++ & ++ & ++ & ++ & + & + & + \\
\hline & ZIM 50 & ++ & ++ & ++ & ++ & + & + & - & - & - & - & - \\
\hline & RELAXYL & ++ & ++ & + & + & - & - & - & - & - & - & - \\
\hline
\end{tabular}

+ slow growth, ++ moderate growth, - no growth of DM\% with respect to control (without any treatment). In both the cases lemongrass and Palmarosa oil, showed lesser degree of antifungal activities in terms of reduction in DM\%, through these two oils had shown better activities in previous experiments (Table 5).

3.6 Effect of different fungicides against test pathogens, and comparison of activity of essential oils

It was observed that $A$. niger could tolerate Curex (copper oxychloride 50\% WP), Zim 50 (carbedazim 50\% WP) and Relaxyl (metalaxyl $80 \%+$ mancozeb $64 \%$ WP) upto 500, 200, and 20ppm in medium respectively and recorded as MIC values for the particular fungicide (Table 6). Similarly, $F$. oxysporum could grow at 500, 50 and 20ppm of Curex, Zim 50 and Relaxyl in the medium respectively. Both Curex and Carbendazim are regarded as contact fungicides have less effect on both the test pathogens, however, Relaxyl, the systemic fungicide showed better activities against the test pathogens. Similar effect was also observed while studying reduction in dry matter percentage (Table 7)

\section{Discussion}

Present investigation proved that all the essential oils had in vitro antifungal activity against the test fungi $A$. niger and F.oxysporum. The varying susceptibility of the pathogens towards the oils was reflected from preliminary test like DDM and secondary methods like MIC through tube dilution method. The MIC value of the oils ranged from $0.97-500 \mu \mathrm{l} / \mathrm{ml}$. Lower MIC value of essential oils against these fungi is reported by several scholars (Rath, 2007; Das et al., 2012; Rath \& Mohapatra, 2015). Essential oils have been used against post harvest fungi like Aspergillus and Fusarium spp. (Bishop \& Thornton, 1997; Soliman \& Badeaa 2002; Fandohan et al., 2004; Tullio et al., 2007; Tolouee et al., 2010; Manssouri et al., 2016). In corroboration to findings of present study Sharma et al. (2016b) 
Table 7 Antifungal activity of fungicides against A. niger and F. oxysporum, in terms of dry matter percentage (DM \%) reduction

\begin{tabular}{|c|c|c|c|}
\hline \multirow{2}{*}{ Sl. No. } & \multirow{2}{*}{ Fungicides } & \multicolumn{2}{|c|}{ Dry Matter Percentage (in mg) } \\
\hline & & A. Niger & F. oxysporum \\
\hline 1 & Curex & 68.95 & 75.33 \\
\hline 2 & Zim-50 & 76.13 & 68.32 \\
\hline 3 & Relaxyl & 60.0 & 67.3 \\
\hline 4 & Control & 74.83 & 70.70 \\
\hline
\end{tabular}

*Fungicides were supplemented into the medium at MIC level

observed antifungal activity of lemongrass, Eucalyptus and Pipermint essential oils against the wilt fungus $F$. oxysporum. Several studies have focused on potential use of essential oil applications against A. niger (Mahmoud 1994; Bankole \& Joda 2004; Mostafa et al., 2013).The activities of the essential oils reported to be fungicidal, as no growth was observed on subculturing the test pathogens onto PDA plates when treated with the oils.

During present investigation, it was observed that Lemongrass and Palmarosa oils have immediate killing effect on A. niger . Antibacterial and antifungal activity of essential oils have been reported by Gupta et al. (2004) and Rath et al. (2005) indicating that when the oils come in contact with the organism it results in irreversible damage to the cell and killing of the pathogen. The antifungal activity of the essential oils is again confirmed through reduction in mycelia growth when, the fungi were cultured in the medium at MIC level of the oils. Immediate antifungal activity of palmarosa oil and lemongrass oils against A. niger as observed in present study indicates that both the oils cause an irreversible damage to the pathogens when it comes in contact of the oil mixture. It is believed that lipophilic nature of essential oils may facilitate in the penetration of lipid bilayer fungal membrane and cause membrane disruption, resulting in death of the fungi (Ultee et al., 2000; Lambert et al., 2001). Further, Gill \& Holley (2006) and Devi et al. (2010) also reported that essential oils disintegrate the cell membrane causing the major alteration in cell permeability, could lead to the leakage of cell constituents and subsequently death of $F$. oxysporum as observed during present study. The changes in the electron flow through the electron transport system inside the mitochondria damage the lipids, proteins and nucleic acid contents (Arnal Schnebelen et al., 2004) of the fungal cells. The essential oils could also hassle the depolarization of the mitochondrial membranes by decreasing the membrane potential, affect $\mathrm{Ca}^{2+}$ and other ion channels, reduce the $\mathrm{pH}$ and also affect the proton pump thereby affecting the ATP pool (Yaoon et al., 2000; Burt, 2004). The change in the fluidity of membranes resulted into the leakage of radicals, cytochrome $\mathrm{C}$, calcium ions and proteins. Thus the permeabilization of outer and inner mitochondrial membranes leads to the cell death by apoptosis and necrosis (Yoon et al., 2000). Further, it was observed the retention of the antifungal activity of these essential oils against these two pathogens on heating $\left(100^{\circ} \mathrm{C}\right)$ and autoclaving, indicates the antifungal compounds present in these essential oils are of thermostable and barostable in nature (Gupta et al., 2004; Rath \& Mohapatra, 2015).

While the activity of commercial fungicides were studied, it was observed, that both the test pathogens could tolerate up to a higher concentration in the medium in comparison to essential oils (Table $2 \& 6$ ). It was also observed that contact fungicides like Curex and Carbendazim have less effect, in comparison to Relaxyl, the systemic fungicide against both the pathogens. In corroboration to findings of present study, Amini \& Sidovich (2010) observed similar observations against $F$. oxysporum. In conclusion it can be notify that the data obtained during this investigation provide substantial information in support of essential oils as natural agents for the control of $F$. oxysporum and A. niger instead of costly, harmful fungicides. However, further scientific investigations are essential in terms of bioformulations, toxicity, halflife, cost etc. for commercial use, in order to tap the potential of these products as biocontrol agents.

\section{Acknowledgement}

The authors are grateful to the Head, Department of Botany, and Director, College of Basic Science and Humanities, Orissa University of Agriculture and Technology (OUAT), Bhubaneswar, for all their encouragement and support.

\section{Conflicts of interest}

All authors declare that there is no conflict of interest.

\section{Refferences}

Amin J, Sidovich DF (2010) The effect of fungicides on Fusarium oxysporum F. Sp. Lycopersci associated with Fusarium wilt of tomato. Journal of Plant Protection Research 50: 172-178. 
Arnal-Schnebelen B, Hadji-Minaglou F, Peroteau JF, Ribeyr F, de Billerbeck VG (2004) Essential oils in infectious gynecological diseases: a statistical study of 658 cases. International Journal of Aromatherrapy 14 : 192-197.

Bankole SA, Joda AO (2004) Effect of lemongrass (Cimbopogan citrates Stapf) powder and essential oil on mould deterioration and aflatoxin contamination of melon seeds (Colosynthis citrullus L.). African Journal of Biotechnology 3: 52-59.

Bauer AW, Kirby WM, Sherris JC, Truck M (1966) Antibiotic susceptibility testing by a standardized single disc method. American Journal of Clinical Pathology 45: 493-496.

Beg AZ, Ahmad I (2002) In vitro fungitoxicity of of the essential oil of Syzygium aromaticum. World Journal of Microbiology and Biotechnology 18: 313-315

Bishop CD, Thornton IB (1997) Evaluation of antifungal activity of the essential oils of M. citriodora var. citriodora and Melaleuca alternifolia on post harvest pathogens. Journal of Essential Oil Research 9: 77-82.

Burt S (2004) Essential oils: their antimicrobial properties and potential applications in foods-a review. International Journal of Food Microbiology 94-223-253

Carvalho FP (2017) Pesticides, environment, and food safety. Food and Energy Security 6: 48-60.

Chutia M, Bhuyan PD, Pathak MG, Sarma TC, Boruah (2009) Antifungal activity and chemical composition of Citrus reticulate Blanco essential oil against phytopathogens from North East India. LWT-Food Science and Technology 42: 777-780.

Das M, Rath CC, Mohapatra UB (2012) Bacteriology of a most popular street food (Panipuri) and inhibitory effect of Essential oils on bacterial growth. Journal of Food Science and Technology 49 : $564-571$.

De Cal A, Sztejnberg A, Sabuquillo P, Melgarejo P (2009) Management of Fusarium wilt on melon and watermelon by Penicillum oxalicum. Biological Control 51: 480-486.

Deng J, Li W, Peng XL, Hao XH (2013) Study on the potential of antifungal activity of essential oils against fungal pathogens of fruits and vegetables. Journal of Chemical and Pharmaceutical Research 5: 443-446

Devi KP, Nisha SA, Sakthivel R, Pandian SK (2010) Eugenol (an essential oil of clove) acts as an antibacterial agent against $S$. typhi by disrupting the cell membrane. Journal of Ethnopharmacology 130: 107-115.
Deising HB, Reimann S, Pascholati SF (2008) Mechanisms and significance of fungicide resistance. Brazilin Journal of Microbiology 39: 286-295.

Fandohan P, Gbenou JD, Gnonlonfin B, Hell K, Marasas WFO, Wingfield MJ (2004) Effect of essential oils on the growth of Fusarium verticilloides and Fuminisin contamination in corn. Journal of Agricultural Food Chemistry 52: 6824-6829.

Gill AO, Holley RA (2006) Inhibition of membrane bound ATPase of E. coli and M. cytogens by plant oil aromatics. International Journal of Food Microbiology 111: 170-174.

Gupta R, Rath CC, Dash SK, Mishra SK (2004) In vitro antibacterial potential assessment of Carrot (Daucus carota) and Celerey (Apium graveolens) seed essential oils against twenty one bacteria. Journal of Essential Oil Bearing Plants 7: 79-86.

Hashem M, Moharama AM, Zaiedb AA, Salehb FEM (2010) Efficacy of essential oils in the control of cumin root rot disease caused by Fusraium spp. Crop Protection 29: 1111-1117.

Lambert RJW, Scandamis PN, Coote PJ, Nychas GJE (2001) A study of the minimum inhibitory concentration and mode of action of oregano essential oil, thymol and Carvacrol. Journal of Applied Microbiology 91: 453-462.

Linde H, Combrinck S, Ringer TJC, Virijevic S (2006) Chemical composition and antifungal activity of the essential oils of Lippia rehmannii from South Africa. South Africa Journal of Botany 76: $37-42$.

Mahmoud ALE (1994) Antifungal action and antiaflatoxigenic properties of some essential oil constituents. Letters in Applied Microbiology 19: 110-113.

Manssouri M, Znini M, Harrak AEl, Majidi, L (2016) Antifungal activity of essential oil from the fruits of Ammodaucus leucotrichus (Coss. \& Dur.) in liquid and vapour phase against post harvest pathogenic fungi in apples. Journal of Applied Pharmaceutical Sciences 6: 131-136.

Mostafa Z, Parsa S, Jahani M, Mahmoodi S (2013) Antifingal effects of Asafoetida seed essential oil on in vitro growth of five species of plant pathogenic fungi. International Research Journal of Applied and Basic sciences 4:1159-1162.

Pawar VC, Thaker VS (2007) Evaluation of the anti-Fusarium oxysporum f. sp. cicer and anti- Alternaria porri effects of some essential oils. World Journal of Microbiology and Biotechnology 23: 1099-1106. 
Rath CC, Mohapatra S (2015) Susceptibility characterization of Candida spp. to four essential oils. Indian Journal of Medical Microbiology 33: S93-96.

Rath CC (2007) Prospects and challenges of essential oils as natural food preservatives - a review. Food $1: 172-180$.

Rath CC, Dash SK, Mishra RK, Charyulu JK (1999) In vitro evaluation of antimycotic activity of turmeric (Curcuma longa L) essential oil against Candia albicans and Cryptococcus neoformans. Indian Perfumer 43:172-178.

Rath CC, Dash SK, Mshra RK, Rajesswaar Rao BR (2005) Antifungal activity of rose scented Geranium (Pelargonium sp.) essential oil and its constituents. Journal of Essential Oil Bearing Plants 8: 218-223.

Samson RA, Houbraken JAMP, Kuijpers AFA, Frank JM, Frisvad JC (2004) New ochratoxin A or sclerotium producing species of Aspergillus : section Nigri. Studies in Mycology 50 : $45-61$.

Sharma R (2012) Pathogenicity of Aspergillus niger in plants. Cibtech journal of Microbiology 1: 47-51.

Sharma A, Rajendran S, Srivastave A, Sharma S, Kundu B (2016a) Antifungal activity of selected essential oils against $F$. oxysporum f.sp. lycopersici 1322, with emphasis on Syzygium aromaticum essential oil. Journal of Bioscience and Bioengineering 123: 1-6

Sharma M, Sharma RP, Jaryal N, Kumar A (2016b) Influence of long term use of chemical fertilizers and amendments on productivity of maize -wheat and NPK uptake in an acid alfisol. Journal of Environment and Biosciences, 30: 65-69
Siddique SA, Islam R, Jamal AHM, Parvin T, Rahman A (2017) Chemical composition and antifungal properties of the essential oil and various extracts of Mikania scandens (L) willd. Arabian Journal of Chemistry 10: 170-174.

Soliman KM, Badeaa RI (2002) Effect of oil extracted from some medicinal plants on different mycotoxigenic fungi . Food Chemistry and Toxicology 40: 1669-1675.

Tejeswini MS, Sowmya HV, Swarnalatha SP, Negi PS (2014) Antifungal activity of essential oils and their combinations in in vitro and in vivo conditions. Achieves Phytopathoology and Plant Protection 47: 564-570.

Tolouee M, Alinezhad S, Saberi R, Eslamifar A, Zad SJ, Jaimand K (2010) Effect of Matricaria chamomilla L. flower essential oil on the growth and the ultra structure of A. niger var Tieghem. Food Science and Technology 139: 127-133

Tullio V, Nostro A, Mandras N, Dugo P, Banche G, Cannatelli MA, Cuffini AM, Alonzo V, Carlone NA ((2007) Antifungal activity of essential oil against filamentous fungi by broth miccrodilution nad vapour contact methods. Journal of applied Microbiology 102: 1544-1550

Ultee A, Slump RA, Steging G, Smid EJ (2000) Antimicrobial activity of carvacrol towards Bacillus cereus on rice. Journal of Food Protection 63:620-624.

Yoon HS, Moon SC, Kim ND, Park BS, Jeong M H, Yoo YH (2000) Genistein induces optosis of RPE-J cells by opening mitochondrial ATP. Journal of Biochemistry Biophysics Research Communication 276 : 151-156. 